\title{
RURAL EXPERIMENTS WITH THE MANAGEMENT OF BASIC RESOURCES. KEY CHARACTERISTICS OF EUROPEAN ECOVILLAGES AIMING AT PARTIAL SELF-SUFFICIENCY IN WATER, FOOD AND ENERGY
}

\author{
Robert Skrzypczyński ${ }^{1}$
}

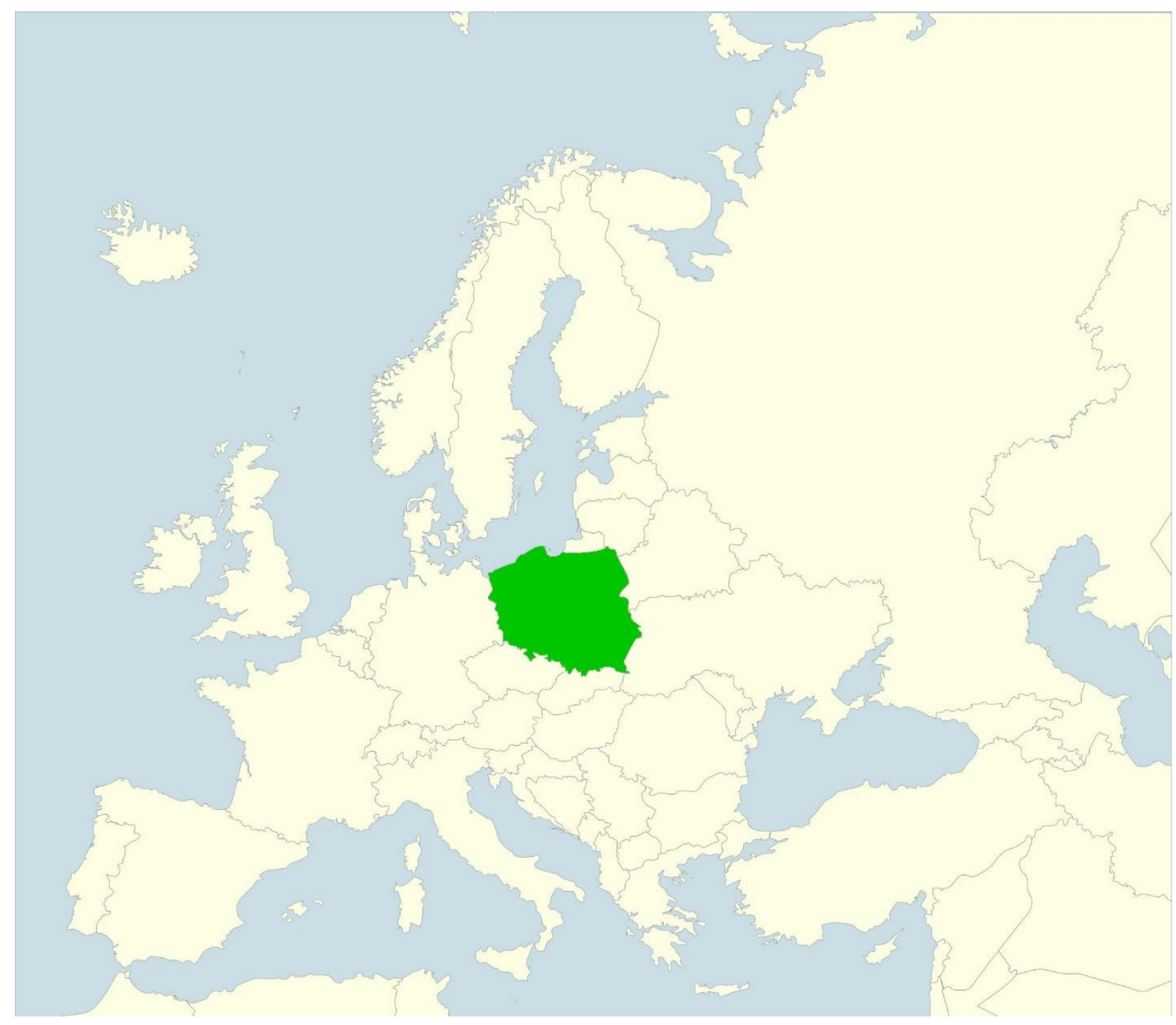

${ }^{1}$ Robert Skrzypczyński, MSc., University of Wroclaw, Faculty of Earth Sciences and Environmental Management, Institute of Geography and Regional Development Wroclaw, Poland; e-mail: robert.skrzypczynski@uwr.edu.pl, ORCID: 0000-0002-6882-6496 
Abstract: The goal of this paper is to provide a preliminary analysis of European ecovillages considered as rural grassroots experiments with the sustainable management of the Water-Energy-Food Nexus. The article presents empirical data on the management of basic resources in 60 European ecovillages collected with an online survey in 2020. The results show that a vast majority of ecovillages pursue some self-sufficiency in food, water or energy, and that $50 \%$ of them seek some selfsufficiency in all three of these resources. However, ecovillages do not try to be completely self-sufficient but rather aim at achieving feasible levels of self-sufficiency complemented with local and regional cooperation. While the role of ecovillages in driving conventional rural growth is limited, they can help in guiding sustainability transitions by illustrating opportunities and difficulties of reducing resource consumption of settlement units without reducing personal and communal well-being.

Keywords: ecovillages, self-sufficiency, socio-technical transitions, Water-Energy-Food Nexus, degrowth

Abstrakt: Celem niniejszego artykułu jest wstępne przeanalizowanie europejskich ekowiosek (tzn. ekologicznie zorientowanych wspólnot intencjonalnych) jako przykładu obecnych na terenach wiejskich oddolnych eksperymentów w zakresie zrównoważonego zarządzania żywnością, wodą i energią. W artykule przedstawiono zebrane w 2020 r. przez kwestionariusz ankietowy on-line dane empiryczne dot. zarządzania podstawowymi zasobami w 60 europejskich ekowioskach. Wyniki wskazują, że większość ekowiosek dąży do samowystarczalności w zakresie wody, żywności lub energii, a 50\% usiłuje uzyskać pewien stopień samowystarczalności w tych trzech obszarach na raz. Jednocześnie ekowioski zwykle nie dążą do całkowitej samowystarczalności, a raczej do jej poziomu możliwego do osiągnięcia w praktyce, współpracując przy tym ze swoim otoczeniem. Ekowioski co prawda nie wpisują się w konwencjonalny paradygmat wzrostu, ale mogą pomóc w transformacji na rzecz zrównoważonego rozwoju dzięki wskazywaniu możliwości i barier obniżania zużycia zasobów w jednostkach osadniczych bez pogorszenia indywidualnej i zbiorowej jakości życia.

Słowa kluczowe: ekowioski, samowystarczalność, przemiany społeczno-techniczne, WaterEnergy-Food Nexus, dewzrost

\section{Highlights:}

- Current socio-technical regimes do not bring about sustainable resource management.

- Ecovillages offer a good opportunity to study alternative socio-technical arrangements.

- Ecovillages are active in most parts of Europe and have diverse basic characteristics.

- Most ecovillages pursue partial - not complete - self-sufficiency in water, food or energy.

- The promise of ecovillages is to guide transitions rather than conventional rural growth.

\section{Introduction}

Sustainability transition demands both significant technological innovations and radical changes in how resources are managed by humans (Haberl et al., 2020). In many areas, such as the necessary reduction of greenhouse gases emissions, the required level of change seems to be extremely far-reaching, particularly given the difficulty in altering the patterns of human consumption and the structural dependence of the dominant socio-economic arrangements on continuous economic growth (Wiedmann et al., 2020). Although the proponents of 'green growth' or 'eco-modernism' argue that technological advancements will be sufficient to reduce the negative impact of humanity on the planet, increasingly often it is claimed that such a feat will 
not be possible without deeper shifts in our socio-economic systems (Weiss and Cattaneo, 2017). Therefore, there is an urgent need to explore alternative models of resource management that would enable living a high-quality life within the safe operating space of planetary boundaries (O’Neill et al. 2018).

In this context, a number of scholars point to the notion of experimentation as a key aspect of enacting sustainability transitions (Hildén, Jordan and Huitema, 2017). Based on a literature review, Sengers, Wieczorek and Raven (2019, p. 162) conceptualize such experiments as 'inclusive, practice-based and challenge-led initiative[s] designed to promote system innovation through social learning under conditions of uncertainty and ambiguity' and proceed to distinguish five types thereof - (1) niche experiments, (2) bounded socio-technical experiments, (3) transition experiments, (4) sustainability experiments and (5) grassroots experiments - that differ in terms of their theoretical foundations, normative goals, mechanisms of operation, analytical emphasis and main actors.

While recognizing a great variety of experiments within each of these types, this paper focuses on the activities of rural ecologically-oriented intentional communities - ecovillages - regarded as an example of grassroots experiments. Grassroots experiments can be defined as experiments performed by "networks of activists and organizations generating novel bottom-up solutions for sustainable development; solutions that respond to the local situation and the interests and values of the communities involved" (Seyfang and Smith, 2007, cited in Sengers et al., 2019, p. 160). They are usually undertaken by representatives of civil society - ecologically-oriented citizens, local communities, informal groups etc. - in order to develop and test innovative models of sustainable socio-technical regimes that could inform wider, ultimately even global transition to sustainability.

A key element of grassroots experiments lies in the innovations they develop - also when they take place in (remote) rural areas. However, innovation tends to be perceived mostly as an urban phenomenon thus resulting in an 'urban bias' in innovation studies (Shearmur, 2017). Obviously, this is not only the case, as there is substantial evidence that innovations emerge in rural areas as well (Esparcia, 2014). Consequently, the innovations introduced by grassroots experiments in rural areas can be important not only because they might help in enacting socio-technical transitions, but also because they can bring about some benefits for the communities in which they occur (Seyfang and Smith, 2007). However, the character of these innovations has to be investigated in more detail in order to assess their potential both for guiding sustainability transition and spurring rural development. Therefore, I argue, rural grassroots experiments and the innovations they introduce deserve attention of scholars, policymakers and other stakeholders both from the fields of transition studies and rural development.

The overarching goal of this paper is thus to explore basic characteristics of European ecovillages in the context of food, water and energy management by answering the following research question: how, and to what extent, are European ecovillages trying to achieve self-sufficiency in basic resources - food, water and energy - that can be informative for developing innovative systems for the provision of basic resources in settlement units in general? In the following section, I review the existing literature on ecovillages with a special emphasis placed on how these communities attempt to become (partly) self-sufficient in basic resources and how this is related to broader sustainability transitions. Then, in section 3, I describe the methodology applied for gathering basic empirical data about European ecovillages. In section 4, I provide empirical data on the approach to the pursuit of self-sufficiency in food, water and energy based on a survey of 60 European ecovillages. I then proceed to discuss the results and conclude that ecovillages can provide a lot of insight into the problems of resource management in settlement units today.

\section{Ecovillages as grassroots experiments with the sustainable management of basic resources - literature review}

\section{Basic characteristics of ecovillages}

In order to define an ecovillage, one has to first consider the definition of intentional communities. According to a widely disseminated definition put forth by Metcalf (2004, p. 9), intentional 
communities are groups of "Five or more people, drawn from more than one family or kinship group, who have voluntarily come together for the purpose of ameliorating perceived social problems and inadequacies". The history of intentional communities stretches back as far as to antiquity (Metcalf, 2012), but only more recently explicitly ecological considerations have become a foremost concern among them (Lockyer, 2017). Correspondingly, the turn of the $21^{\text {st }}$ century saw a growing number of a particular sub-type of ecologically-oriented intentional communities ecovillages - whose members attempt to live in line with the principles of sustainability in small, close-knit communities (Escribano, Lubbers and Molina, 2017).

As the concept of an ecovillage is a relatively new one - with the first definition proposed in 1991 - there is an ongoing discussion on the exact meaning of that term (Dawson, 2013). This stems partly from the evolution of the ecovillages themselves, and partly from the variety of their characteristics and contexts in which they have been established. Moreover, the term has often been defined inconsistently or in an aspirational way, which led to further difficulties in conceiving its precise definition (Nelson, 2018; Moravčíková and Fürjészova 2018; Wagner, 2012). Nevertheless, the definitions of ecovillages usually emphasize recurring motifs which can be considered as their basic characteristics. Thus, an ecovillage can be defined as a permanent human settlement inhabited by an intentional community whose members consciously attempt to live a low-impact lifestyle integrating various dimensions of sustainability - social, environmental, economic or cultural - thereby responding to the perceived global problems such as climate change, fossil fuel depletion or social inequality (Boyer, 2015; Brombin, 2015; Siracusa et al., 2008). Several authors also indicate that ecovillages are usually rural and rarely inhabited by more than a few hundred persons (Dias et al. 2017; Bang, 2005, cited in Van Schyndel Kasper, 2008; Lockyer, 2010). One has to note that as the definition above builds on Metcalf's (2004) definition of intentional communities, it assumes that an ecovillage has at least 5 inhabitants from more than one family or kinship group.

A strong emphasis on community is a key feature of ecovillages. While the term "ecovillage" suggests explicit orientation towards ecological goals, the communal aspect - or, "intentional togetherness" - is usually considered equally important (Litfin, 2012). In consequence, many ecovillages focus on interpersonal relationships, cooperative culture, shared values, social inclusion, non-violent communication, participatory governance just as much as they do on environmental goals. Ecovillages are, therefore, not only trying to learn how to live in harmony with the environment but also, as Mychajluk (2017) puts it, "how to live and work together". Moreover, social and environmental objectives are often not perceived as separate but rather as intrinsically linked in a holistic approach to sustainability of socio-ecological systems (Litfin, 2012). A combination of environmental and social goals is thus what informs concrete practices adopted by ecovillagers.

The Global Ecovillage Network (2021) database lists 415 ecovillages in the world today; this number, however, includes self-designated ecovillages and should be therefore treated with caution. Moreover, not every existing ecovillage is a member of GEN, and some might prefer to keep a low-profile e.g., to avoid an excessive number of visitors that would be difficult to manage by the community. Moreover, ecovillages very often fail to survive the first years of their functioning (Barani, Alibeygi and Papzan, 2018), which means that their number can vary with time. There is, however, a core group of established ecovillages such as Findhorn Ecovillage (Scotland), Sieben Linden Ecovillage (Germany), ZEGG (Germany), Tamera (Portugal), Cloughjordan (Ireland), Damanhur (Italy), Auroville (India) or the Dancing Rabbit Ecovillage (USA) - to name just a few. Some of these have been active for decades now, in many cases being set up as intentional communities before the term 'ecovillage' was coined.

There are a number of ways in which ecovillages try to realize their environmental goals. In their recent review, Barani et al. (2018) enumerate various practices of ecovillages related to the management of basic resources: growing and preserving food, composting organic waste, securing water supply from on-site wells, harvesting rainwater, making use of locally available renewable energy sources or, finally, lowering the overall demand for resources of the community in various ways (e.g., by reducing car usage, constructing energy efficient houses or preventing food waste). In general, ecovillages try to close the loops of resource flows to the largest extent possible in order to protect and regenerate the natural environment and form a productive, vibrant 
community. In doing so, ecovillages become partly self-sufficient to a larger or lesser extent: for instance, a recent assessment of the Sieben Linden ecovillage conducted by Bocco et al. (2019) indicates that in 2014 , the community achieved $67 \%$ self-sufficiency in electricity, $100 \%$ in heat supply, $61 \%$ in water and $29 \%$ in food production (including $64 \%$ for vegetables and $35 \%$ for fruits); and as the authors conclude, there is still hope to increase at least some of these ratios. Furthermore, numerous studies confirmed that the ecological and carbon footprints of ecovillages are significantly (35-50\%) lower than average footprints of the respective regions in which they are located (Daly, 2017).

\section{The pursuit of self-sufficiency in ecovillages}

Although the pursuit of (partial) self-sufficiency - i.e., generating resources needed for the functioning of the community on-site by its own members - is not always included into the definitions of ecovillages, a number of them pursue some degree of autonomy in various aspects of the community life (Daly, 2017; Kunze and Avelino, 2015; Brombin, 2015; Escribano et al., 2017; Meijering, 2007; Van Schyndel Kasper, 2008). Striving for some level of selfsufficiency is linked to various goals such as: achieving low environmental footprint (Daly, 2017), creating virtuous cycles of resources in order to regenerate local environment in line with the concept of permaculture (Litfin, 2012), seeking financial savings or resilience from global economic crises (Escribano et al. 2017; Renau, 2018) or gaining independence from the supralocal infrastructure networks linked to the unsustainable practices of modern societies (Litfin, 2013). As Lockyer (2017) notes, in pursuing certain level of local autonomy, ecovillages try to internalize the externalities linked to the modus operandi of the contemporary global economy. Finally, the vision of achieving (partial) self-sufficiency in ecovillages can also be related to philosophical inquiries in the spirit of voluntary simplicity (Farkas, 2017).

What is important to note is that the goal of self-sufficiency is not necessarily linked to seeking isolation and independence from the wider society. Dawson (2013) argues that today - in contrast to the early days of the movement - ecovillages do not function as "islands", but rather they maintain various relations with local and regional stakeholders and the society at large, by e.g., organizing workshops, sharing technological innovations or partnering with educational institutions. This approach has its reflection in the provision of basic resources too. If an exemplary ecovillage twenty years ago would probably seek absolute self-sufficiency in electricity by trying to construct its own off-grid system, today it would more often be connected to grid with the goal of becoming a zero net energy community. Sometimes, notwithstanding economic considerations, ecovillages even become net energy suppliers (Litfin, 2013). An illustrative example of this approach comes from the Dancing Rabbit's Ecovillage whose members agreed on a covenant allowing grid connection of a house only if its renewable energy installations generated yearly twice more electricity than its estimated demand (Lockyer, 2017). This shift illustrates what other authors noted too, namely that rather than escaping from mainstream society, ecovillages try to develop alternative practices which in their view form part of the necessary socio-technical transition to global sustainable living (Waerther, 2014; Litfin, 2013). One of such practices is the maximum possible localization of energy generation, food production and water supply - and hence the pursuit of at least partial self-sufficiency in basic resources of many ecovillages. This approach to self-sufficiency also means that ecovillages seldom intend to become completely self-sufficient with no attention paid to the costs (ecological, economic or other) that complete self-sufficiency requires; rather, they try to achieve the highest levels of self-sufficiency feasible in given circumstances.

So far, however, little research has been conducted on how and with what results ecovillages realize that goal. Many studies - primarily analyses of ecological or carbon footprints of ecovillages - include some data on the achieved levels of self-provision of some resources but since their focus lies elsewhere, they do not provide enough insight into how exactly this is realized. On the other hand, even more numerous studies of ecovillages conducted from the perspective of human sciences (see Wagner, 2012) do not include adequately detailed calculations of energy and material flows managed by the community and therefore do not allow to fully comprehend the problem too. As a result, we still lack proper understanding of the complexity of pursuing self-sufficiency in basic resources - especially when it comes to 
the quantification of inputs necessary to achieve it as well as the occurrence of interconnections between the flows of water, food and energy managed by the community. What could be therefore particularly helpful in this context is the utilization of the Water-Energy-Food (WEF) Nexus framework - an approach that takes these factors into consideration, and which in recent years has been recognized as crucial for understanding the provision of basic resources for human settlement systems (Mannan et al., 2018).

\section{Experiments with self-sufficiency as an element of sustainability transition}

A deeper understanding of how self-sufficiency is being pursued is important not only for the ecovillages themselves, but also for a wider socio-technical transition to sustainable resource provision systems. Indeed, many scholars emphasize the significance of ecovillages as places of experimentation with alternative lifestyles that can guide the transition to a sustainable society (Kirby, 2017; Daly, 2017; Litfin, 2013; Dawson, 2013). In particular, given that ecovillages are often defying the paradigm of (green) growth, ecovillages can be seen as de facto grassroots experiments of hypothetical societies that follow the logic of degrowth.

Degrowth is a multi-faceted concept used in various meanings ${ }^{2}$, but it is generally based on the recognition that in order to scale human activity back into the safe operating space within planetary boundaries, we have to intentionally reduce the biophysical size of the global economy (Cosme, Santos and O'Neill, 2017). As the term "degrowth" suggests, it is a contestation of the imperative of unlimited economic growth, and it questions its role for the welfare of humans (and non-human animals too). While recognizing that many people, particularly in the Global South, do live in material and energy poverty, degrowth calls for a significant reduction of resource consumption in the wealthy societies of the Global North and promotes less material- and energyintensive socio-technical regimes that could enable everyone on the planet to live well. The reason why degrowth emphasizes a need for a wide socio-technical transition and deeper cultural changes in contrast to mere adjustments of the status quo is that so far, the postulates of green growth - e.g., that technological improvements and free market mechanisms are sufficient for the necessary change to occur - seem at best unlikely to materialize (Hickel and Kallis, 2019). This is so mostly because decoupling economic growth from resource use and carbon emissions is not occurring at a pace even remotely close to the pace that is necessary to prevent crossing various planetary boundaries - and it does not seem likely to occur in the future (Haberl et al., 2020).

The convergence of degrowth with the normative goals of ecovillages led some authors to recognize ecovillages as de facto grassroots degrowth experiments (Demaria et al., 2015; Renau, 2018), even if the concept of degrowth is seldom referred to directly by the ecovillages. This analogy seems to be grounded in the fact that ecovillages are seeking substantial self-sufficiency in basic resources not just to isolate themselves, but rather due to a recognition that contemporary settlement units need to devise new models of social metabolism that would limit their negative impact on the planet while increasing their resilience to the consequences of climate change or resource scarcity. What is important to qualify such approach as convergent with degrowth is that this goal is being achieved not only by changing the sources of food, water or energy used or consumed by the community (e.g., switching to renewable energy sources or growing organic food), but also by active demand-side management that manifests itself in intentionally reducing the levels of material and energy throughput required to sustain the functioning of the community in a good shape. In doing so, ecovillages are redefining how much energy and materials are required for living a satisfactory life, and this reflects the core idea of degrowth. And there is some evidence of their success: Lockyer (2017) observed that the inhabitants of the Dancing Rabbit Ecovillage maintain high quality of life despite consuming as little as even $10 \%$ of the per capita average of the US and according to the findings of Jovic (2004), practical inconveniences of living in ecovillages do not seem to hinder achieving personal satisfaction. One reason for that is

\footnotetext{
2 The term 'degrowth' is usually used in three meanings-as a political slogan, a name of a social movement, and a scientific concept (Demaria et al., 2013). Although it is not possible to completely separate this uses, here I focus on the scientific use of this term.
} 
explained by Kirby (2003) who notes that following a sustainable lifestyle brings about a sense of personal integrity which counterbalances its technical difficulties.

Ecovillages are especially relevant to the studies on degrowth because they integrate different aspects of this approach in a concrete place and community (Heikkurinen, 2018; Lockyer 2010). Obviously, it does not mean that a significant part of global population should, or is going to, live in ecovillages. Nevertheless, ecovillages can and do function as sources of socio-technical innovations transferred to the wider society in various ways (Boyer, 2015; Nelson, 2018; Dias et al. 2017). Such innovations may include particular practices, technologies or lifestyles that are then adapted by actors outside of the community. But what is perhaps the most valuable feature of ecovillages as objects of study is that due to their local character, they provide a perfect opportunity to examine the broader picture of how pursuing degrowth-oriented self-sufficiency is realized in practice and what otherwise unexpected limitations - or chances - it can present for communities that will choose, or will have to follow, a degrowth transition in the future.

Apart from guiding global socio-technical transitions by creating niche experiments in sustainable resource management that could be up-scaled, translated or replicated elsewhere, ecovillages are also linked to the concept of degrowth in a more direct way. It is often argued that degrowth implies not only a need to reduce the global biophysical size of the economy, but also to "relocalize" the provisioning of at least some of the resources used by settlement units (Xue, 2014). While the local scale should not be promoted uncritically (Born and Purcell, 2006), degrowth proponents often argue that under current conditions, localization is simply more suitable for living a life characterized by downscaled resource consumption, communal cooperation, personal productivity and high levels of subjective well-being (Alexander and Yacoumis, 2018). At the same time, the fact that focusing on the local scale is not sufficient for a global degrowth transition is recognized too (Asara et al., 2015). Seen in this light, however, localization of resource management is not only a way to experiment in niches with developing a global degrowth transition, but is also one of the postulates of degrowth in itself (cf. Xue, 2014). Again, this does not mean that everyone should move to ecovillages - but localization of resource management, as exemplified by ecovillages, is still a strategy worth investigating.

\section{Methods and data sources}

The empirical data presented in Section 4 of this paper were collected in a survey realized in 2020 with the help of an on-line questionnaire. The questionnaire form (see Appendix 1) was prepared using the KoBo Toolbox software, a free tool for on-line data collection, and it contained questions related to basic features of the ecovillages as well as their approach to the management of water, food and energy. A link to the questionnaire was sent by e-mail to 392 ecologically-oriented rural intentional communities in Europe that had been pre-identified on the basis of databases publicly available on the Internet from the Global Ecovillage Network (GEN), GEN Europe, Baltic Ecovillage Network, Fellowship for Intentional Community, Ecobasa and national networks of ecovillages in European countries ${ }^{3}$. These sources were complemented by the list of ecovillages published in Eurotopia Directory (2014). The questionnaire was filled out by 60 communities, 13 of which asked to remain partly or completely anonymous; in consequence, appropriate data that enable identifying these communities have been anonymized. Out of these 60 communities, 55 can be classified as ecovillages according to the definition provided in section 2 . The remaining 5 are either inhabited by less than 5 people, or are active only in summer and not inhabited throughout the entire year. However, I decided to keep these 5 communities in the database mainly because of the fact that ecovillages are highly dynamic communities that can quickly grow into 'official' ecovillages (that meet all the definition criteria), but also so that other researchers have access to the information about these communities that they could use for the purpose of their research activities. These communities have been appropriately marked in the list of all surveyed communities (Annex 2).

\footnotetext{
3 These national networks are: Rete Italiana Villaggi Ecologici (Italy), Landsforeningen for Okosamfund (Denmark), Red Ibérica de Ecoaldeas (Spain and Portugal), GEN Nederland, GEN Russia, GEN Deutschland (Germany), GEN Finland, Norske Økosamfunns Forening (Norway), Ekobyarnas Riksorganisation (Sweden) and GEN Ukraine.
} 
The database contained in Annex 2 is an important source of data on the basic characteristic of ecovillages, but it should be treated with some caution, as the data provided by communities have not been verified by field research. Moreover, the category of self-sufficiency used in the questionnaire is a broad one and refers to the intuitive understanding of self-sufficiency rather than a detailed, universal definition. However, given the fact that this survey serves only for gathering initial, general data on the management of basic resources, I decided not to complicate the questionnaire beyond what was necessary for this purpose - also because the rate of responses would most probably be lower in such case.

Still, a significant number of ecovillages did not respond to the request to fill in the questionnaire - the response rate was only $17 \%$. What can be interesting for other researchers is that some communities clearly stated that they see no point in filling in another on-line questionnaire that brings back no benefits to the community itself; the respondents noted that in the past, the researchers did not provide the results of their inquiries, and consequently the effort of the eco-villagers put into participating in studies seemed pointless. Moreover, several communities pointed out that qualitative research methods that include visits in the communities would be more appropriate to reflect the complexity of ecovillages. This partly explains the low rate of responses and suggests a need to choose the methods with awareness of this problem in the future research on ecovillages.

\section{Results - empirical data on the pursuit of self-sufficiency in food, water and energy in European ecovillages}

\section{Basic characteristics}

Ecovillages are present in virtually all parts of Europe - the communities that filled in the survey are located in 21 countries (Fig. 1). The countries that top the list of responses to the questionnaire are Italy (8), Sweden (6) and Denmark (6). A lack of ecovillages in Central-Eastern Europe is visible, but this does not have to mean that there are no active communities in this region; however, other sources point to the fact that, indeed, there are few recognized ecovillages in countries such as Poland, Czechia, Slovakia or Hungary (Global Ecovillage Network, 2021). Out of the 60 responses provided in the survey, 50\% (30) are from established communities, $42 \%$ (25) are under construction or reconstruction, and 5\% (5) are in the planning phase (2 of which have already selected the site). Therefore, the map in the Fig. 1 shows 57 ecovillages in total 55 actual settlements and 2 that are in planning phase at a selected site.

The ecovillages that participated in the survey represent a diverse set of communities. In terms of basic characteristic - population, area and time in operation - they range from 4 to 250 inhabitants, from less than 0.5 ha to over 400 ha, and from just 1 to as much as 56 years in operation. (Tab. 1). For each of these parameters, however, the mean values are consistently higher than the median values, which suggests a relative prevalence of less populous, smaller and younger ecovillages within the surveyed communities.

Tab 1. Basic characteristic of the surveyed ecovillages. Source: own work

\begin{tabular}{|c|c|c|c|}
\hline & Population [-] & Area [ha] & Years in operation \\
\hline Lowest value & 4 & 0.45 & 1 \\
\hline Highest value & 250 & 414.00 & 56 \\
\hline Mean & 53 & 55.39 & 16 \\
\hline Median & 19 & 10.75 & 10 \\
\hline
\end{tabular}




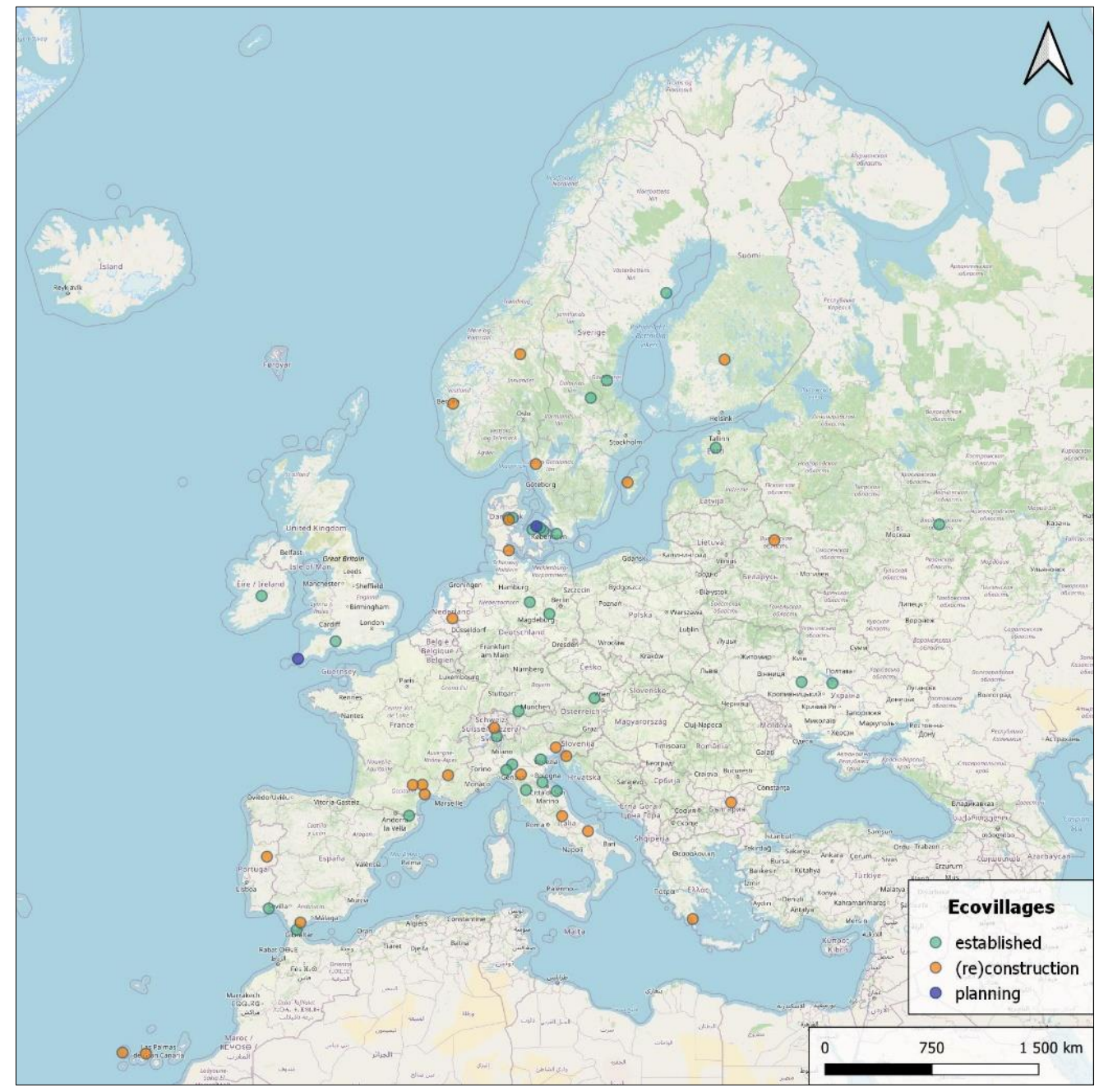

Fig 1. Geographical distribution of the communities that participated in the survey. Source: own work; Open Street Map basemap licensed under the Open Data Commons Open Database License

\section{Pursuing self-sufficiency}

Within the 60 surveyed communities, a vast majority (93\%; 56 communities) have achieved, or in case of the ecovillages in the planning phase - intend to, achieve some level of self-sufficiency in at least one of the three resources in question, i.e., food $(80 \%$ of communities), water $(77 \%)$ or energy $(75 \%)$. However, only $50 \%$ are interested in (partial or complete) self-sufficiency in all three of these resources simultaneously (Fig. 2).

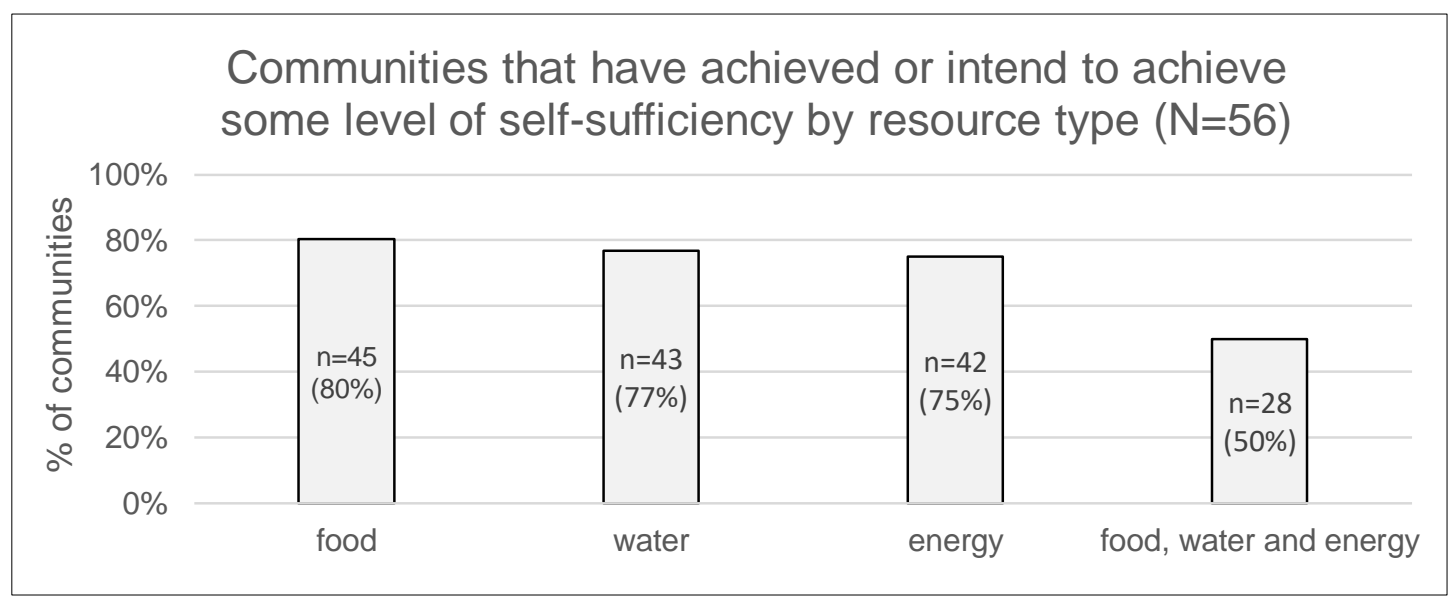

Fig 2. The shares of surveyed ecovillages that have achieved or intend to achieve some level of self-sufficiency in food, water or energy. Source: own work 
The data on the achieved and planned levels of self-sufficiency reveal that - except for water ecovillages do not usually achieve, or even seek, complete self-sufficiency in basic resources (Fig. 3). In terms of food, the majority of ecovillages currently have 'low' or 'medium' levels of food self-sufficiency, and are planning to achieve a 'medium' or (less frequently) a 'very high' level of self-sufficiency. In terms of energy, there are already some communities who declare to have achieved complete self-sufficiency in energy $(21 \%)$, and who are trying to do that $(45 \%)$. It is only in the case of water that complete self-sufficiency is a goal for a clear majority of the surveyed ecovillages, as the percentage of communities that achieved, or are planning to achieve, complete self-sufficiency is substantial ( $69 \%$ and $79 \%$, respectively).

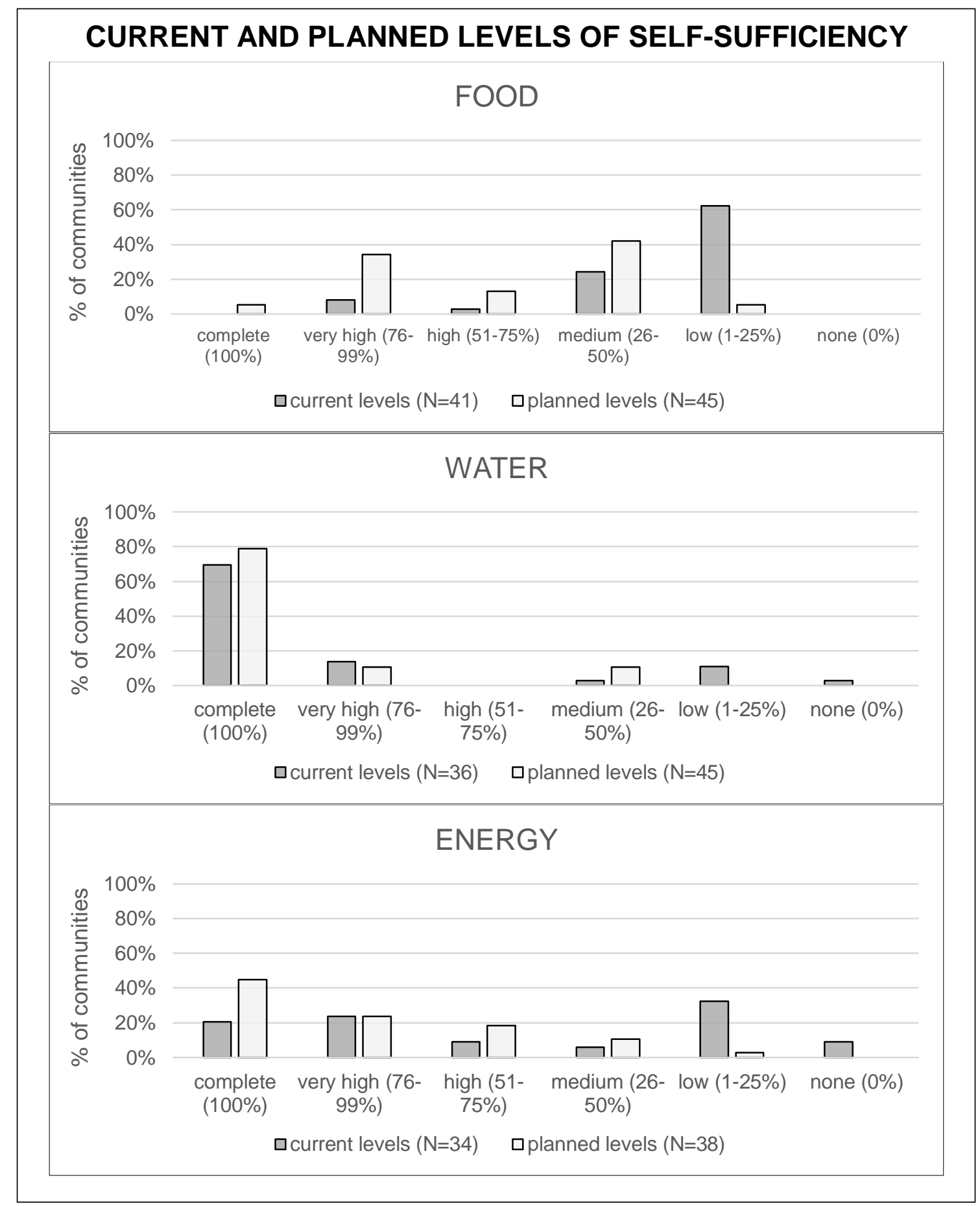

Fig 3. Current and planned levels of self-sufficiency in the surveyed ecovillages. Source: own work 


\section{Technologies used in the pursuit of self-sufficiency}

Given that ecovillages are mostly rural communities, they generally employ conventional methods related to food production: land cultivation, composting or soil regeneration techniques (Fig. 4). While cultivating land, $42 \%$ (14) of the communities used machines and $18 \%$ (6) kept animals for this purpose. Less traditional methods are not popular - none of the ecovillages constructed a vertical farm, and only $8 \%$ used hydro- or aquaponics for food production. On the other hand, wild food foraging and forest gardening were relatively popular (ca. $40 \%$ of communities in both cases; 16 and 17 communities, respectively). Moreover, $5 \%$ of ecovillages collect food that is purposed to be thrown away by shops or restaurants nearby.

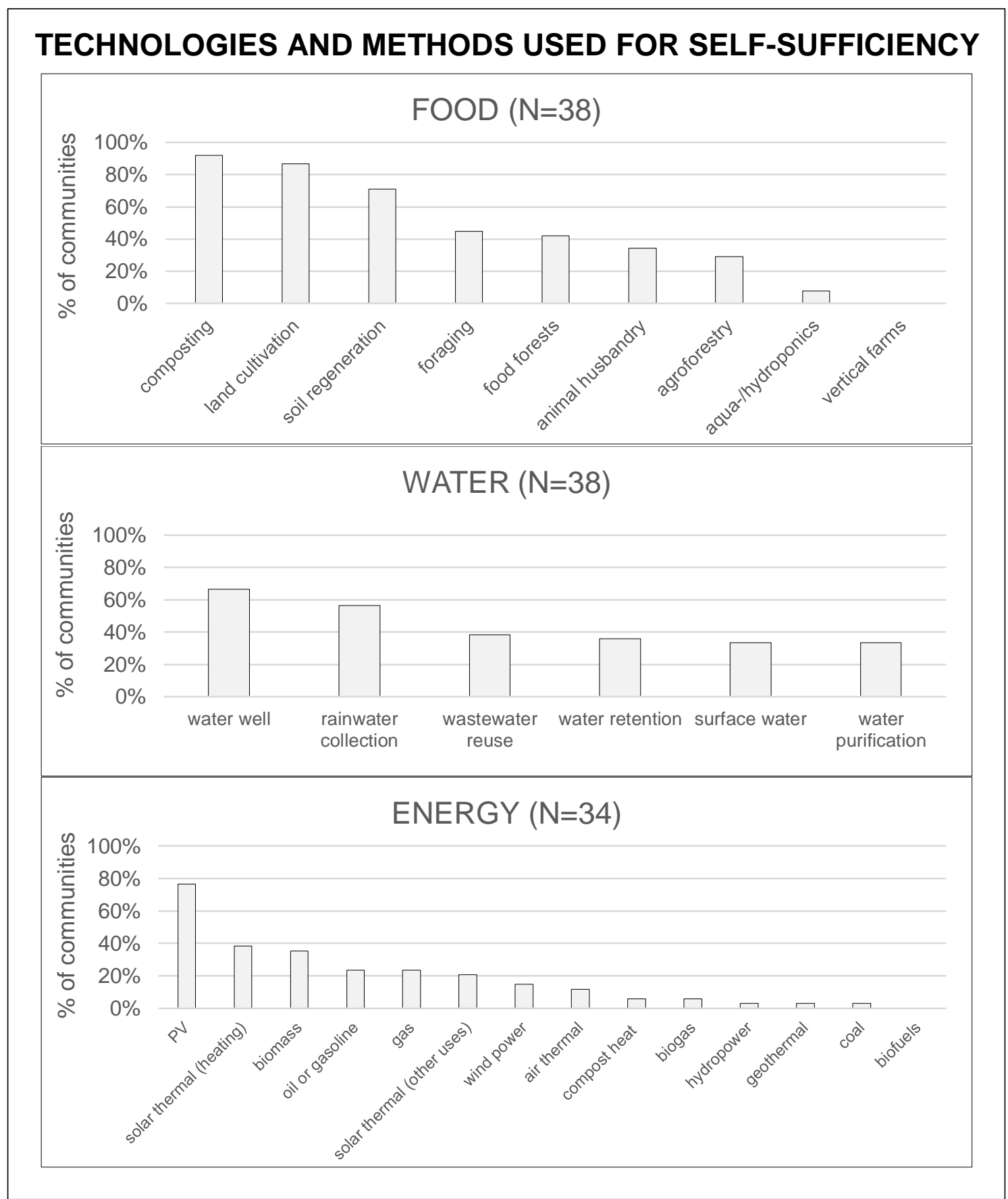

Fig 4. Technologies and methods used by the surveyed ecovillages in the pursuit of self-sufficiency. Source: own work

The provisioning of water for the communities was realized mostly with on-site water wells $(68 \%)$. Surface water such as springs or streams are used by one-third of the communities. More than half $(58 \%)$ of the communities are engaged in rainwater collection, and more than one-third $(37 \%)$ 
in water retention in the natural environment. Only $24 \%$ (9) of the surveyed ecovillages interested in water self-sufficiency are connected to the water supply network.

In terms of energy, photovoltaic panels are by far the most popular method for energy provision (76\% of communities), followed by solar thermal collectors used for heating (38\%) and biomass $(35 \%)$. At the same time, $43 \%$ of communities do employ some type of energy storage - both in terms of electrical (31\% of communities) and thermal energy (20\%). However, $65 \%$ (24) of the surveyed ecovillages interested in energy self-sufficiency are still connected to the electrical grid.

\section{Factors predicting higher self-sufficiency levels of ecovillages}

In order to explain the characteristic of ecovillages that help them become more self-sufficient, a Spearman correlation test was run to verify possible correlations between the current (declared) levels of self-sufficiency and 4 selected variables: (1) years in operation of the ecovillage, (2) number of residents, (3) its area and (4) technological diversity, i.e., the number of technologies/methods used in the respective domains of food production, water supply and energy generation. These 4 variables have been chosen due to their hypothesized positive correlation with achieved self-sufficiency levels; i.e., that higher self-sufficiency levels would be achieved in communities that had been active longer, have more population and a larger area, and employ more methods related to resource provisioning. The results (Tab. 2), however, show that only two variables are statistically correlated with higher levels of self-sufficiency: 'older' ecovillages (more years in operation) tend to have higher levels of self-sufficiency in food, and 'larger' ecovillages (larger area) are associated with higher levels of self-sufficiency with respect to water. In both cases, however, the correlations coefficients are not very high (.390 and .561, respectively).

Tab. 2. Correlation of current (declared) self-sufficiency levels with selected variables (source: own work). Correlations with significant levels within 0.05 are marked with an asterisk.

\begin{tabular}{|c|l|c|c|c|c|}
\cline { 3 - 5 } \multicolumn{2}{c|}{} & $\begin{array}{c}\text { Years in } \\
\text { operation }\end{array}$ & Population & Area & $\begin{array}{c}\text { Number of used } \\
\text { technologies }\end{array}$ \\
\hline \multirow{3}{*}{ FOOD } & Correlation Coefficient & $.390^{*}$ & .116 & .322 & .113 \\
\cline { 2 - 6 } & Significance (2-tailed) & .019 & .625 & .224 & .517 \\
\cline { 2 - 6 } & $\mathrm{N}$ & 36 & 20 & 16 & 35 \\
\hline \multirow{3}{*}{ WATER } & Correlation Coefficient & .044 & -.335 & $.561^{*}$ & -.306 \\
\cline { 2 - 6 } & Significance (2-tailed) & .797 & .205 & .046 & .074 \\
\cline { 2 - 6 } & $\mathrm{N}$ & 36 & 16 & 13 & 35 \\
\hline \multirow{3}{*}{ ENERGY } & Correlation Coefficient & .195 & -.282 & -.026 & .219 \\
\cline { 2 - 6 } & Significance (2-tailed) & .269 & .273 & .926 & .220 \\
\cline { 2 - 6 } & $\mathrm{N}$ & 34 & 17 & 15 & 33 \\
\hline
\end{tabular}

\section{Discussion and conclusions}

The results of the survey indicate that pursuing some level of self-sufficiency in food, energy or water is a common phenomenon among ecovillages. However, only in half of the cases do communities seek self-sufficiency simultaneously in all three analysed resources - water, energy and food. This somehow limits the possibility of studying ecovillages in the context of integrated Water-Energy-Food Nexus management; nonetheless, ecovillages are probably still among the most relevant initiatives for inquires in how these resources can be managed sustainably in an integrated way at the scale of a settlement unit.

At the same time, ecovillages generally are not, nor are they trying to be, completely self-sufficient in basic resources. This confirms the observation of Dawson (2013) that ecovillages are not trying to isolate themselves from wider society, but rather to cooperate with their local or regional communities while covering a substantial but feasible part of the demand for basic resources on 
their own. Water is an exception in this case, as the majority of the surveyed ecovillages are, and are planning to be, completely self-sufficient in water supplies. What has to be noted too is that although complete energy self-sufficiency is not a universal goal among ecovillages, still over $40 \%$ of communities intend to reach it.

The results related to what technologies are employed in the pursuit of self-sufficiency also confirm the conclusions of Rubin (2019) indicating that ecovillages are neither primitivist, nor modernist, as they make use of technologies they need to achieve their purposes, and that are easily available to them. The strength of ecovillages as grassroots experiments with sustainability transition lies therefore not in the development of new technologies as such (although there are some examples of that, too), but in the integration of technologies into communal practices that together can serve as a testing ground for how new socio-technical regimes of basic resources management could look like in the future.

The preliminary analysis of selected factors that can explain higher levels of self-sufficiency declared by the communities does not yield very clear conclusions. Only two factors seem to have an impact on the achieved self-sufficiency levels: one in terms of food (years in operation of the community) and one in terms of water (area of the ecovillage). Given that self-sufficiency is a rate between the in situ generation and consumption of resources, it is clear that achieved levels of self-sufficiency depend not only on the production-side, but also demand-side components. With the same levels of production, lower demand - e.g., resulting from less resource-intensive diets, water recycling or energy conservation - will automatically increase self-sufficiency rates. Therefore, future investigations of self-sufficiency should look in detail into the absolute levels of demand for water, food and energy associated with various communal arrangements and practices. Moreover, it would be highly recommendable to adopt research designs that would assure a coherence between the data on self-sufficiency levels gathered from various ecovillages, which in case of this study are based on a simplified definition of self-sufficiency adopted in order to enable the collection of data with the use of an on-line questionnaire.

The characteristics of ecovillages suggest that they have limited potential for stiring rural development understood conventionally as revolving around economic growth. Ecovillages do intend to improve the quality of life of their residents, but rather by creating a new model of development that puts more emphasis on quality of life achieved by sufficiency, subsistence, personal productivity, care, communal cooperation and respect towards nature. Therefore, the question to what extent ecovillages can contribute to rural regeneration depends how one defines regeneration; in any case, ecovillages show a potential in enhancing rural resilience, environmental restoration (e.g., soil regeneration) or communal cooperation. It seems, though, that due to the microscale of ecovillage experiments, their potential lies more in their relevance for guiding sustainability transitions in general rather than in their direct translation for broader rural development. Nevertheless, ecovillages are still very relevant for local and regional development in those areas where they are located.

One has to remember that ecovillages are grassroots initiatives with limited financial and organizational resources that could help in experimenting with new socio-technical arrangements for sustainability. Therefore, what could be important in this context is public support provided e.g., within the frameworks of transition management with the goal of testing and spreading the socio-technical innovations developed in ecovillages. This, however, requires recognizing the importance of innovations not only as market-oriented products, but also as sustainable communal arrangements and practices that often may contest the dominant logic of "development-as-growth".

There are a range of issues related to self-sufficiency of rural intentional communities that have been only briefly mentioned in this paper. In fact, pursuing self-sufficiency poses questions related to how self-sufficiency is measured, what the boundaries of the analysed system are, or what types of infrastructures are used by the studied communities for the provision of food, water and energy. Also, a number of possible drivers and limitations of self-sufficiency could be examined in future studies: socio-economic factors (e.g., access to funding, access to social networks, knowledge and skills), geographical aspects (e.g., climate or the availability of renewable energy sources), legal context (regulations of resource provisioning) as well as cultural phenomena (e.g., 
perception of self-sufficiency in a particular society). Finally, and as the surveyed communities indicated themselves, future studies on resource provisioning in ecovillages should also consider employing qualitative methodologies that could help deepen the understanding of a number of issues, for instance, how many inputs are used to achieve particular self-sufficiency levels, what are the ways in which the demand for resources is minimized, or how the functioning of the community changes in different parts of the year. Further research on self-sufficiency seems important not only for ecovillages, but for sustainable provisioning of resources at a global scale, as this is the scale at which humanity eventually has to be (sustainably) self-sufficient. While I will focus my attention on these questions in future research, I hope that this paper will provide a base for other researchers to investigate these issues too.

\section{Acknowledgements}

This paper has been produced in the framework of the RURALIZATION project, which has received funding from the European Union's Horizon2020 research and innovation programme (grant agreement no. 817642). The paper reflects only the authors' view and the European Commission is not responsible for any use that may be made of the information it contains.

Academic references

[1] Alexander, S. \& Yacoumis, P. (2018). Degrowth, energy descent, and "low-tech" living: Potential pathways for increased resilience in times of crisis. Journal of Cleaner Production, 197(2), 1840-1848. DOI: 10.1016/j.jclepro.2016.09.100.

[2] Asara, V., Otero, I., Demaria, F. \& Corbera, E. (2015). Socially sustainable degrowth as a social-ecological transformation: repoliticizing sustainability. Sustainability Science, 10(3), 375-384. DOI: 10.1007/s11625-015-0321-9.

[3] Barani, S., Alibeygi, A. \& Papzan, A. (2018). A framework to identify and develop potential ecovillages: Meta-analysis from the studies of world's ecovillages. Sustainable Cities and Society, 43, 275-289. DOI: 10.1016/j.scs.2018.08.036.

[4] Bocco, A., Gerace, M. \& Pollini, S. (2019). The Environmental Impact of Sieben Linden Ecovillage. London: Routledge.

[5] Born, B. \& Purcell, M. (2006). Avoiding the Local Trap. Journal of Planning Education and Research, 26(2), 195-207. DOI: 10.1177/0739456X06291389.

[6] Boyer, R. (2015). Grassroots innovation for urban sustainability: Comparing the diffusion pathways of three ecovillage projects. Environment and Planning A, 47(2), 320-337. DOI: 10.1068/a140250p.

[7] Brombin, A. (2015). Faces of sustainability in Italian ecovillages: Food as "contact zone". International Journal of Consumer Studies, 39(5), 468-477. DOI: 10.1111/ijcs.12225.

[8] Cosme, I., Santos, R. \& O'Neill, D. (2017). Assessing the degrowth discourse: A review and analysis of academic degrowth policy proposals. Journal of Cleaner Production, 149, 321334. DOI: 10.1016/j.jclepro.2017.02.016.

[9] Daly, M. (2017). Quantifying the environmental impact of ecovillages and co-housing communities: a systematic literature review. Local Environment, 22(11), 1358-1377. DOI: 10.1080/13549839.2017.1348342.

[10] Dawson, J. (2013). From Islands to Networks. The History and Future of the Ecovillage Movement. In Lockyer, J. \& Veteto, J., eds., Environmental Anthropology Engaging Ecotopia. Bioregionalism, Permaculture, and Ecovillages (pp. 217-234). New York: Berghahn.

[11] Demaria, F., Schneider, F., Sekulova, F. \& Martinez-Alier, J. (2013). What is degrowth? From an Activist Slogan to a Social Movement. Environmental Values, 22(2), 191-215. DOI: $10.3197 / 096327113 X 13581561725194$. 
[12] Dias, M., Loureiro, C. Chevitarse, L. \& de Mello e Souza, C. (2017). The Meaning and Relevance of Ecovillages for the Construction of Sustainable Societal Alternatives. Ambiente \& Sociedade, 20(3), 79-96.

[13] Escribano, P., Lubbers, M. \& Molina, J. (2017). Becoming Part of an Eco-Community: Social and Environmental Activism or Livelihood Strategy? Social Sciences, 6(4), 148-163. DOI: $10.3390 /$ socsci6040148.

[14] Esparcia, J. (2014). Innovation and networks in rural areas. An analysis from European innovative projects. Journal of Rural Studies, 34, 1-14. DOI: 10.1016/j.jrurstud.2013.12.004.

[15] Farkas, J. (2017). To Separate from the Umbilical Cord of Society. Freedom as Dependence and Independence in Hungarian Ecovillages. Etnofoor, 29(1), 81-100.

[16] Haberl, H., Wiedenhofer, D., Virág, D., Kalt, G., Plank, B., Brockway, P., Fishman, T., Hausknost, D., Krausmann, F., Leon-Gruchalski, B., Mayer, A., Pichler, M., Schaffartzik, A., Sousa, T., Streeck, J. \& Creutzig, F. (2020). A systematic review of the evidence on decoupling of GDP, resource use and GHG emissions, part II: Synthesizing the insights. Environmental Research Letters, 15(6), 1-42. DOI: 10.1088/1748-9326/ab842a.

[17] Heikkurinen, P. (2018). Degrowth by means of technology? A treatise for an ethos of releasement. Journal of Cleaner Production, 197, 1654-1665. DOI: 10.1016/j.jclepro.2016.07.070.

[18] Hickel, J. \& Kallis, G. (2019). Is Green Growth Possible? New Political Economy, 25(4), 469486. DOI: $10.1080 / 13563467.2019 .1598964$.

[19] Hildén, M., Jordan, A. \& Huitema, D. (2017). Special issue on experimentation for climate change solutions editorial: The search for climate change and sustainability solutions The promise and the pitfalls of experimentation. Journal of Cleaner Production, 169, 1-7. DOI: 10.1016/j.jclepro.2017.09.019.

[20] Jovic, E. V. (2004). Lighter Footprints: Quality of Life Correlates, Mindfuless and the Sustainability Movement [Master thesis]. The University of Calgary.

[21] Kirby, A. (2003). Redefining social and environmental relations at the ecovillage at Ithaca: A case study. Journal of Environmental Psychology, 23(3), 323-332. DOI: 10.1016/S02724944(03)00025-2.

[22] Kirby, P. (2017). Cloughjordan Ecovillage: Modelling the Transition to a Low-Carbon Society. In Garcia, E., Martinez-Iglesias, M. \& Kirby, P., eds., Transitioning to a Post-Carbon Society. Degrowth, Austerity and Wellbeing (pp. 183-205). London: Palgrave Macmillan.

[23] Kunze, I. \& Avelino, F. (2015). Social Innovation and the Global Ecovillage Network. [TRANSIT Research Report]. Rotterdam: Erasmus University.

[24] Litfin, K. (2012). A Whole New Way of Life: Ecovillages and the Revitalization of Deep Community. In De Young, R. \& Princen, T., eds., The Localization Reader. Adapting to the Coming Downshift (pp. 129-140). Cambridge (MA): MIT Press.

[25] Litfin, K. (2013). Ecovillages. Lessons for Sustainable Community. Cambridge: Polity Press.

[26] Lockyer, J. (2010). Intentional community carbon reduction and climate change action: from ecovillages to transition towns. In Peters, M., Fudge, S. \& Jackson, T. (2010). Low Carbon Communities. Imaginative Approaches to Combating Climate Change Locally (pp. 197-215). Cheltenham: Edward Elgar Publishing.

[27] Lockyer, J. (2017). Community, commons, and degrowth at Dancing Rabbit Ecovillage. Journal of Political Ecology, 24, 519-542. DOI: 10.2458/v24i1.20890.

[28] Mannan, M., Al-Ansari, T., Mackey, H. R. \& Al-Ghamdi, S. G. (2018). Quantifying the energy, water and food nexus: A review of the latest developments based on life-cycle assessment. Journal of Cleaner Production, 193, 300-314. DOI: 10.1016/j.jclepro.2018.05.050. 
[29] Meijering, L., van Hoven, B. \& Huigen, P. (2007). Constructing ruralities: The case of the Hobbitstee, Netherlands. Journal of Rural Studies, 23(3), 357-366. DOI: 10.1016/j.jrurstud.2007.01.002.

[30] Metcalf, B. (2004). The Findhorn Book of Community Living. Findhorn: Findhorn Press.

[31] Metcalf, B. (2012). Utopian Struggle: Preconceptions and Realities of Intentional Communities. In Andreas, M. \& Wagner, F., eds., Realizing Utopia. Ecovillage Endeavors and Academic Approaches (pp. 21-29). Munich: Rachel Carson Center for Environment and Society.

[32] Moravčíková, D. \& Fürjészová, T. (2018). Ecovillage as an Alternative Way of Rural Life: Evidence from Hungary and Slovakia. European Countryside, 10(4), 693-710. DOI: 10.2478/euco-2018-0038.

[33] Mychajluk, L. (2017). Learning to live and work together in an ecovillage community of practice. European Journal for Research on the Education and Learning of Adults, 8(2), 181196. DOI: 10.3384/rela.2000-7426.rela9092.

[34] Nelson, A. (2018). Small is Neccessary. Shared Living on a Shared Planet. London: Pluto Press.

[35] O'Neill, D. W., Fanning, A. L., Lamb, W. F. \& Steinberger, J. K. (2018). A good life for all within planetary boundaries. Nature Sustainability, 1(2), 88-95. DOI: 10.1038/s41893-0180021-4.

[36] Renau, L. (2018). Ecovillages in Spain: Searching an emancipatory social transformation? Cogent Social Sciences. Cogent, 4(1), 1-18. DOI: 10.1080/23311886.2018.1468200.

[37] Rubin, Z. (2019). Ecovillagers' assessment of sustainability: Differing perceptions of technology as a differing account of modernism. Sustainability, 11(21), 6167. DOI: $10.3390 /$ su11216167.

[38] Sengers, F., Wieczorek, A. J. \& Raven, R. (2019). Experimenting for sustainability transitions: A systematic literature review. Technological Forecasting and Social Change, 145, 153-164. DOI: 10.1016/j.techfore.2016.08.031.

[39] Shearmur, R. (2017). Urban bias in innovation studies. In Bathelt, H. Cohendet, P. Henn, S. \& Simon, L., eds., The Elgar Companion to Innovation and Knowledge Creation (pp. 440456). Cheltenham: Edward Elgar Publishing.

[40] Siracusa, G., La Rosa, A., Palma, P. \& La Mola, E. (2008). New frontiers for sustainability: Emergy evaluation of an eco-village. Environment, Development and Sustainability, 10(6), 845-855. DOI: 10.1007/s10668-007-9087-2.

[41] Van Schyndel Kasper, D. (2008). Redefining community in the ecovillage. Human Ecology Review, 15(1), 12-24.

[42] Waerther, S. (2014). Sustainability in Ecovillages - A Reconceptualization. International Journal of Management and Applied Research, 1(1), 1-16. DOI: 10.18646/2056.11.14-001.

[43] Wagner, F. (2012). Ecovillage Research Review. In Andreas, M. \& Wagner, F., eds., Realizing Utopia. Ecovillage Endeavors and Academic Approaches (pp. 21-29). Munich: Rachel Carson Center for Environment and Society.

[44] Weiss, M. \& Cattaneo, C. (2017). Degrowth - Taking Stock and Reviewing an Emerging Academic Paradigm. Ecological Economics, 137, 220-230. DOI: 10.1016/j.ecolecon.2017.01.014.

[45] Wiedmann, T., Lenzen, M., Keyßer, L. T. \& Steinberger, J. K. (2020). Scientists' warning on affluence. Nature Communications, 11(1), 1-10. DOI: 10.1038/s41467-020-16941-y.

[46] Würfel, M. (2014). Eurotopia Directory: Communities and Ecovillages in Europe. Sieben Linden: Sieben Linden Ecovillage. 
[47] Xue, J. (2014). Is eco-village/urban village the future of a degrowth society? An urban planner's perspective. Ecological Economics, 105, 130-138. DOI: 10.1016/j.ecolecon.2014.06.003.

Other sources

[48] Global Ecovillage Network (2021) Ecovillages. [online]. Available at: https://ecovillage.org/projects/ [Accessed 01.03.2021]. 